\title{
SGOT, SGPT and Hepatitis B Antigen in Leprosy
}

\author{
S. S. KELKAR \\ Department of Microbiology, Medical College, \\ A urangabad, India \\ K. B. NIPHADKAR \\ Department of Microbiology, B. J. Medical College, \\ Poona, India \\ P. M. KHARE \\ Department of Pathology and Bacteriology, \\ B. J. Medical College, Poona, India \\ and \\ P. V. KASBEKAR \\ Sassoon General Hospitals, Poona, India
}

\begin{abstract}
Serum glutamic pyruvic transaminase (SGPT) and serum glutamic oxaloacetic transaminase (SGOT) levels were determined in seven cases of tuberculoid leprosy carrying hepatitis $\mathrm{B}$ antigen ( $\mathrm{HB}-\mathrm{Ag}$ ) and comparecl with the levels in $50 \mathrm{HB}$ Ag-negative cases of tuberculoid leprosy. The mean value for SGPT and SGOT in the former group was 7.86 and $8.86 \mathrm{IU} / \mathrm{L}$ respectively, while in the latter it was 9.08 and 11.48 respectively. Similarly the mean values for SGPT and SGOT in eight HB Ag-positive cases of lepromatous leprosy were 8.88 and 13.75 IU/L respectively while the mean figures for $50 \mathrm{HB}$ Ag-negative cases of lepromatous leprosy were 7.96 and $12.48 \mathrm{IU} / \mathrm{L}$ respectively. The differences obtained in lepromatous leprosy were statistically insignificant. There was no difference in the serum enzyme levels of $\mathrm{HB}$ Ag-positive and negative cases and the range of values obtained were comparable. The absence of liver damage as indicated by enzyme studies suggests the host-parasite relationship of the hepatitis B virus in leprosy to be one of symptomless carriage.
\end{abstract}

\section{Introduction}

Hepatitis B antigen (HB-Ag), a surface antigen of the Hepatitis B virus, occurs more frequently in sera of patients with leprosy than in the normal populations (Blumberg et al, 1967; Blumberg and.Melartin, 1970a). The interaction between man and this virus shows an intriguing variety of host-parasitic relationships which 
range from symptomless carriage, through mild chronic liver injury which can lead to cirrhosis of the liver to the explosive attack of acute viral hepatitis (Sherlock et al, 1970). Carriage of HB antigen in leprosy is possibly of two types (1) harmless carriage and/or (2) associated with mild hepatic damage. Blumberg and Melartin $(1970 b)$ studied liver function in 28 cases of lepromatous leprosy carrying HB antigen and found that only the SGPT levels, though often in the normal range, were significantly higher than those in a similar number of leprosy patients not carrying the antigen. The inference was that the hepatitis B virus caused mild liver injury. Post-mortem studies in the literature, however, do not record cirrhosis of the liver to be a common occurrence in patients with leprosy (Kean and Childress, 1942). This rarity of cirrhosis suggests that HB antigen carriage is not frequently associated with chronic liver injury.

We have had occasion to study HB antigen carriage in a large series of leprosy patients (Kelkar et al., 1973b). During these studies, SGPT and SGOT levels of some of the patients with and without $\mathrm{HB}$ antigen were estimated, with a view to investigate the nature of the host-parasitic relationship of the hepatitis $B$ virus carriage in patients with leprosy.

\section{Material and Methods}

The patients consisted of seven with tuberculoid and eight with lepromatous leprosy all of whom had HB antigen in their sera. For a comparison, 50 patients with tuberculoid and 50 with lepromatous leprosy and not carrying the $\mathrm{HB}$ antigen, were studied. Sera from these patients were tested for SGOT and SGPT levels by the method of Reitman and Frankel (1957). Detection of HB-Ag was done by both agar gel double diffusion and a counter immunoelectrophoretic technique (Kelkar et al., 1974; Kelkar et al., 1972).

\section{Results}

Figures 1 and 2 are scatter diagrams illustrating the values for SGPT and SGOT obtained in the patients studied. Table 1 gives the mean figures for the different groups as well as the numbers of cases showing raised enzyme levels. The accepted upper normal limits for SGPT and SGOT are 15 and 20 IU/L respectively

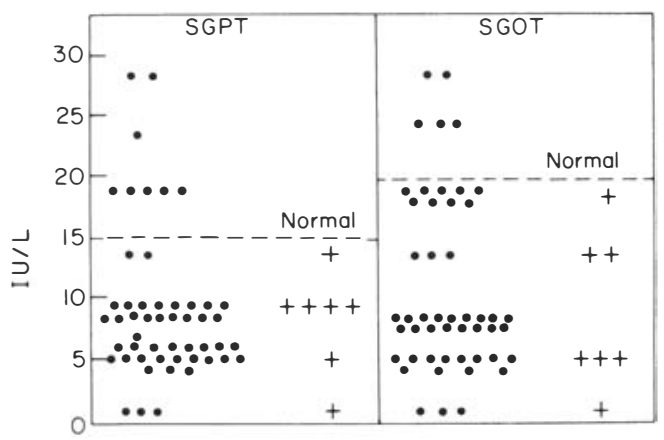

Fig.1. Scatter diagram showing SGPT and SGOT levels of cases of tuberculoid leprosy. $+=$ $\mathrm{HB}-\mathrm{Ag}$ positive case; $\bullet=\mathrm{HB}-\mathrm{Ag}$ negative case. 


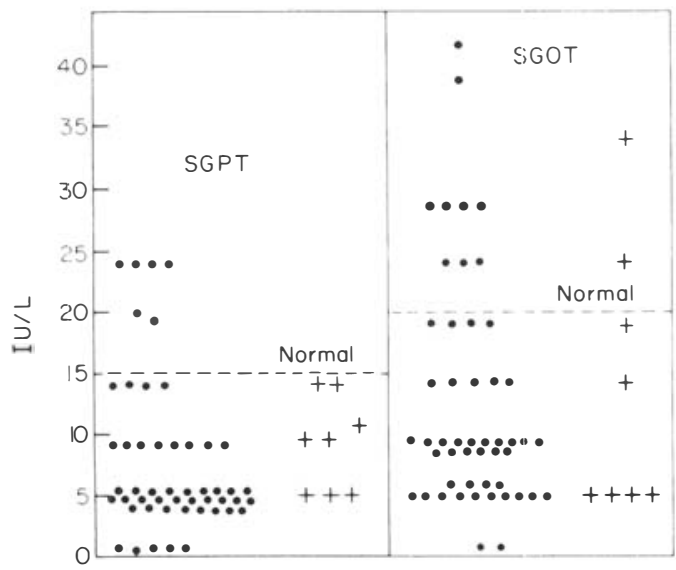

Fig.2. Scatter diagram showing SGPT and SGOT levels of cases of lepromatous leprosy. $+=$ $\mathrm{HB}-\mathrm{Ag}$ positive case $; \bullet=\mathrm{HB}-\mathrm{Ag}$ negative case

(Wooton, 1964). A reference to the table shows that the mean enzyme values of the $50 \mathrm{HB}-\mathrm{Ag}$ negative cases of tuberculoid leprosy are actually higher than the means for the seven cases which showed presence of antigen in the serum. The scatter diagram (Fig.1) shows that the range and values obtained are not essentially different. Moreover none of the $\mathrm{HB}-\mathrm{Ag}$ positive cases had abnormal (raised) enzyme levels.

With lepromatous leprosy the results obtained were slightly different. The mean value of enzymes obtained in 50 cases of lepromatous leprosy not carrying HB-Ag were lower than those obtained with HB-Ag carriers having lepromatous leprosy. These slight differences, however, when analyzed by statistical methods proved to be of no significance $(P=0.54$ and 0.68$)$. A glance at the scatter diagram (Fig.2) again brings out the essential similarity of the results in the two groups.

TABLE 1

SGPT and SGOT (International Units/L) in HB-Ag positive and negative patients with leprosy

\begin{tabular}{|c|c|c|c|c|c|c|}
\hline & GROUP & $\begin{array}{l}\text { No. of } \\
\text { cases }\end{array}$ & $\begin{array}{l}\text { SGPT } \\
\text { Mean } \\
\text { value }\end{array}$ & $\begin{array}{l}\text { No. of cases } \\
\text { with SGPT } \\
\text { over } 15 \mathrm{IU} / \mathrm{L}\end{array}$ & $\begin{array}{l}\text { SGOT } \\
\text { Mean } \\
\text { value }\end{array}$ & $\begin{array}{c}\text { No. of cases } \\
\text { with SGOT } \\
\text { over } 20 \mathrm{IU} / \mathrm{L}\end{array}$ \\
\hline \multirow[t]{3}{*}{ (I) } & Tuberculoid & 57 & & & & \\
\hline & HB-Ag negative & 50 & 9.08 & 8 & 11.48 & 5 \\
\hline & HB-Ag positive & 7 & 7.86 & 0 & 8.86 & 0 \\
\hline \multirow[t]{3}{*}{ (II) } & Lepromatous & 58 & & & & \\
\hline & HB-Ag negative & 50 & 7.96 & 6 & 12.48 & 9 \\
\hline & HB-Ag positive & 8 & 8.88 & 0 & 13.75 & 2 \\
\hline
\end{tabular}




\section{Discussion}

The results for SGPT and SGOT, in general, are in keeping with the well documented observations that there are no serious derangements of liver function in leprosy (Shivde and Junnarkar, 1967). Progressive liver damage due to Myco. leprae is not known. Further, the results indicate that there is no difference in the enzyme levels in cases of leprosy with or without carriage of the hepatitis B virus. The inference that can be validly drawn is that the hepatitis B virus does not damage the hepatocyte to cause a rise in enzyme levels. Of the available tests these enzyme estimations are the most sensitive indicators of hepatic parenchymal damage. The interaction between the hepatitis B virus and the leprosy patient, therefore, appears to be that of symptomless carriage.

We still do not know for certain the outcome of symptomless HB-Ag carriage either in the leprosy patient or in normal individuals. The very fact that the hepatitis B virus is present in the serum in such large amounts as to be detected by relatively crude immunological methods indicates a considerable growth of the virus. The accepted site for this is the hepatocyte (Millman et al, 1969). Therefore disruption of some hepatocytes and hepatic damage is unquestionable. The point of interest is whether there is sufficient damage to disorganize normal liver regeneration so that a terminal condition like cirrhosis of the liver develops with the passage of years. A sequential follow-up study would finally decide this issue.

A lot of data is available in the literature regarding the condition of normal individuals carrying HB-Ag (Lous et al., 1970; Singleton et al., 1971; Lebacq, 1971; Ricci et al., 1972). These studies prove that a variable number of HB-Ag carriers have hepatic injury, with the likelihood of development of cirrhosis of the liver.

Cirrhosis of the liver is not a common finding in patients with leprosy. Thus Kean and Childress (1942) noted cirrhosis in only seven of 103 patients studied at autopsy in Panama. Similarly Shivde and Junnarkar (1967), studying liver biopsies, found only five of 43 cases to have cirrhosis of the liver. In contrast, in a study of portal cirrhosis in patients without leprosy we have found as many as $34 \%$ to be associated with HB-Ag (Kelkar et al., 1973a). This raises the question of the relationship of $\mathrm{HB}-\mathrm{Ag}$ with cirrhosis of the liver in patients with leprosy. Because of the rarity of the combination, a study of a large series of such cases is not feasible. The indirect evidence of enzyme levels presented in the present study suggests that this is not a frequent happening.

\section{References}

Blumberg, B. S. and Melartin, L. (1970a). Australia antigen and lepromatous leprosy. Studies in South India and elsewhere. Int. J. Lepr. 38, 60. ×

Blumberg, B. S. and Melartin, L. (1970b). Australia antigen and hepatitis; studies in lepromatous leprosy patients and in asymptomatic individuals living in the tropics. Arch. Int. Med. 125, 287.

Blumberg, B. S., Melartin, L., Lechat, M. and Guinto, R. S. (1967). Association between lepromatous leprosy and Australia antigen. Lancet ii, 173.

Kean, B. H. and Childress, M. E. (1942). A summary of 103 autopsies on leprosy patients on the Isthmus of Panama. Int. J. Lepr. 10, 51.

Kelkar, S. S., Karhade, N. V. and Bhagwat, R.B.(1973a). A ustralia/hepatit is associated antigen in cirrhosis of the liver at Aurangabad. Ind.J. Med. Res. 61, 1614.

Kelkar, S. S., Niphadkar, K. B. and Karve, S. R. (1974). The agar gel double diffusion test for detection of the Australia antigen. J. Postgrad. Med. 20, 35. 
Kelkar, S. S., Niphadkar, K. B. and Khare, P. M. (1972). Immunoelectrophoresis (counterimmunoelectrophoresis) for detection of the Australia antigen. Med. J. West. Ind. 5,18 .

Kelkar, S. S., Niphadkar, K. B., Khare, P. M. and Junnarkar, R. V. (1973b). Hepatitis B antigen in a leprosy hospital. Bull. Wld Hlth Org. 48, 555.

Lebacq, E. (1971). Liver disease in carriers of Australia antigen, Lancet ii, 977.

Lous, P., Olesen, H. and Skinhoj, P. (1970). Hepatitis-Associated (Au-SH) antigen determination in 10,000 patients in a Copenhagen general hospital. Lancet ii, 119.

Millman, I., Zavatone, V., Gerstley, B. S. and Blumberg, B. S. (1969). Australia antigen detected in the nuclei of liver cells of patients with viral hepatitis by the fluorescent antibody technique. Nature, Lond. 222, 181.

Reitman, S. and Frankel, S. (1957). A colorimetric method for determination of serum glutamic oxaloacetic and glutamic pyruvic transaminase. Amer. J. Clin. Path. 28, 56.

Ricci, G., DeBae, C. and Caramia, F. (1972). Liver disease in Australia antigen carriers. Lancet i, 494.

Sherlock, S., Fox, R. A., Niazi, S. P. and Scheuer, P. J. (1970). Chronic liver disease and primary liver-cell cancer with hepatitis-associated (Australia) antigen in serum. Lancet i, 1243.

Shivde, A. V. and Junnarkar, R. V. (1967). Serum transaminase activity in leprosy in relation to liver damage. Int. J. Lepr. 35, 366.

ingleton, J. W., Fitch, R. A., Merrill, D. A., Kohler, P. F. and Rettberg, W. A. H. (1971). Liver disease in Australia-antigen-positive blood donors. Lancet ii, 785.

Wooton, I. D. P. (1964). Microanalysis in Medical Biochemistry. 4th Edition. London: J. and A. Churchill Ltd. 